\title{
Disfungsi Konjungsi dalam Makalah Mahasiswa
}

\author{
Giati Anisah \\ anisahgiati@gmail.com \\ Institut Agama Islam Sunan Giri Bojonegoro
}

\begin{abstract}
Abstrak: Penelitian ini bertujuan untuk mendeskripsikan disfungsi konjungi dalam makalah mahasiswa. Dari deskripsi tersebut disimpulkan pula pola kesalahan penggunaan konjungsi yang dilakukan mahasiswa. Penelitian ini adalah penelitian kualitatif dengan jenis penelitian deskriptif. Data dalam penelitian ini adalah teks dalam makalah mahasiswa Prodi Pendidikan Agama Islam semester tiga Institut Agama Islam Sunan Giri Bojonegoro. Dari serangkaian analisis disimpulkan disfungsi konjungsi pada makalah mahasiswa dialami oleh konjungsi untuk, dan, karena, sebab, dengan, namun, dan maka. Pola umum kesalahan penggunaan konjungsi pada makalah mahasiswa adalah penempatan konjungsi intrakalimat koordinatif pada awal kalimat dan pemborosan konjungsi.
\end{abstract}

Kata Kunci: Karya Ilmiah, Pedoman, Analisis

\section{A. PENDAHULUAN}

Praktik penggunaan bahasa tulis membutuhkan kompetensi gramatikal yang mumpuni. Kemampuan tersebut penting agar wacana yang dihasilkan bersifat kohesi dan koheren. Kohesi merupakan organisasi sintaksis dan penyusunan kalimat-kalimat secara padu serta padat untuk menghasilkan kalimat atau tuturan. ${ }^{1}$ Perangkat kohesi menghubungkan bagian-bagian wacana dalam satu kesatuan teks. ${ }^{2}$ Kemampuan menyusun kalimat atau paragraf yang kohesif tercermin pada kemampuan menata ide, bentuk kata, serta kalimat yang tepat.. Kohesi dibagi menjadi dua, yaitu kohesi gramatikal dan kohesi leksikal. ${ }^{3}$ Kohesi gramatika berkaitan dengan aspek gramatikal dalam wacana yang meliputi referensi, substitusi, elipsis, dan konjungsi. Salah satu penanda kohesi gramatikal untuk

\footnotetext{
${ }^{1}$ Henry Guntur Tarigan, 2009, Pengantar Wacana, (Bandung: Angkasa Bandung), halaman 93

${ }^{2}$ H. G. Widdowson, 2007, Discourse Analysis, (New York: Oxford University Press), halaman 46

${ }^{3}$ M. Halliday dan R. Hasan, 1976, Cohesion in English, (London: Longman), halaman 6
} 
membentuk kalimat dan paragraf yang sering mengalami kesalahan penggunaa adalah konjungsi.

Konjungsi adalah kategori kata yang berfungsi untuk menghubungkan kata dengan kata, frasa dengan frasa, klausa dengan klausa, kalimat dengan kalimat, dan paragraf dengan paragraf. ${ }^{4}$ Konjungsi dapat berupa kata maupun frasa. Penempatan konjungsi dalam teks harus tepat agar menunjukkan keruntutan makna teks sehingga mudah dipahami oleh pembaca. Sebagai alat sintaksis, konjungsi berfungsi untuk memperluas satuan sintaksis, baik dalam konstruksi setara maupun tidak setara. $^{5}$

Berdasarkan letaknya konjungsi dibagi menjadi dua, yaitu konjungsi intrakalimat dan konjungsi antarkalimat. Konjungsi intrakalimat menghubungkan konstituen dalam satu kalimat. Konjungsi antarkalimat merupakan bagian dari kalimat, tetapi jika dilihat dari aspek fungsi dan aspek semantiknya sudah berkaitan dengan kalimat-kalimat lain dalam konteks wacana. ${ }^{6}$

Berdasarkan perilaku sintaksis dan keintian konstituen yang dihubungkan, konjungsi intrakalimat dibagi menjadi konjungsi koordinatif dan subordinatif. Konjungsi koordinatif berfungsi untuk menghubungkan dua buah konstituen yang memiliki hubungan setara. Terdapat tiga jenis konjungsi koordinatif seperti yang dipaparkan dalam Tabel 1 berikut. $^{7}$

Tabel 1. Jenis Konjungsi Koordinatif

\begin{tabular}{|l|l|}
\hline Jenis & Konjungsi \\
\hline $\begin{array}{l}\text { Konjungsi koordinatif } \\
\text { penambah/pendamping }\end{array}$ & Dan, serta \\
\hline Konjungsi koordinatif pemilihan & Atau \\
\hline Konjungsi koordinatif perlawanan & Tetapi \\
\hline
\end{tabular}

\footnotetext{
${ }^{4}$ Abdul Chaer, 2009, Sintaksis Bahasa Indonesia (Pendekatan Proses), (jakarta: Rineka Cipta), halaman 81

${ }^{5}$ Sumadi, 2009, Sintaksis Bahasa Indonesia, (Malang: UM Press), halaman 155

${ }^{6}$ Ibid, halaman 156

${ }^{7}$ Hasan Alwi. dkk, 2003, Tata Bahasa Baku Bahasa Indonesia,(Jakarta: Balai Pustaka) halaman 298
} 
Terdapat tiga ciri utama konjungsi koordinatif.

a. Bergantung pada unsur yang digabungkannya sehingga ia tidak dapat berdiri sendiri

b. Posisi dan urutannya selalu di belakang konstituen pertama yang digabungkannya

c. dan dan atau dapat menggabungkan lebih dari dua konsituen, akan tetapi tetapi tidak

Konjungsi subordinatif adalah konjungsi yang menghubungan dua klausa yang kedudukannya tidak setara. Klausa yang dihubungkan oleh konjungsi subordinatif harus memiliki perbedaan kedudukan, satu klausa menjadi klausa utama sedangkan satu klausa lainnya menjadi klausa bawahan. Terdapat tiga belas jenis konjungsi subordinatif ${ }^{8}$.

\section{Tabel 2. Jenis Konjungsi Subordinatif}

\section{Jenis}

Konjungsi subordinatif waktu

Konjungsi subordinatif syarat

Konjungsi subordinatif pengandaian

Konjungsi subordinatif tujuan

Konjungsi subordinatif konsensif

Konjungsi subordinatif pembandingan

Konjungsi subordinatif sebab

Konjungsi subordinatif hasil

Konjungsi subordinatif alat

Konjungsi subordinatif cara

Konjungsi subordinatif komplementasi

Konjungsi subordinatif atributif

Konjungsi subordinatif perbandingan

\section{Konjungsi}

Sejak, semenjak, dari, sewaktu, ketika, tatkala, sementara, begitu, seraya, selagi, selama.

Jika, kalau, jikalau, asal(kan), bila, manakala

Andaikan, seandainya, umpama, sekiranya

Agar, supaya, untuk

Biar(pun), meski(pun), walau(pun), sekalipun, sengguhpun, kendati

Seakan-akan, seolah-olah, sebagaimana, seperti, laksana, ibarat Sebab, karena, oleh karena, oleh sebab Sehingga, sampai, maka

Dengan, tanpa

Dengan, tanpa

Bahwa

Yang

Sama dengan, lebih dari

\footnotetext{
${ }^{8}$ Ibid, halaman 289
} 
Ciri-ciri konjungsi subkoordinatif sebagai berikut.

a. Menghubungkan dua klausa yang satu diantaranya merupakan klausa utama dan yang lainnya adalah klausa bawahan

b. Hanya menghubungkan klausa

c. Merupakan bagian dari klausa, klausa yang diawali dengan konjungsi subornatif berperan sebagai anak kalimat

d. Posisi tidak tetap, dapat sebelum atau sesudah induk kalimat.

Konjungsi antarkalimat berfungsi menghubungkan kalimat dengan kalimat ${ }^{9}$. Konjungsi antarkalimat terletak di awal kalimat. Berikut macam-macam konjungsi antar kalimat.

\section{Tabel 3. Jenis Konjungsi Antarkalimat}

\begin{tabular}{|l|l|}
\hline Konjungsi & Contoh \\
\hline $\begin{array}{l}\text { Biarpun demikian, sekalipun, demikian, } \\
\text { walaupun, meskipun, meskipun } \\
\text { demikian }\end{array}$ & $\begin{array}{l}\text { Menyatakan kesediaan untuk } \\
\text { melakukan sesuatu yang berbeda } \\
\text { ataupun bertentangan dengan yang } \\
\text { dinyatakan kalimat sebelumnya }\end{array}$ \\
\hline $\begin{array}{l}\text { Kemudian, sesudah itu, setelah itu, } \\
\text { selanjutnya }\end{array}$ & $\begin{array}{l}\text { Menyatakan kelanjutan dari peristiwa } \\
\text { atau keadaan pada kalimat sebelumnya }\end{array}$ \\
\hline Tambahan pula, lagi pula, selain itu & $\begin{array}{l}\text { Menyatakan adanya hal, peristiwa, atau } \\
\text { keadaan lain di luar dari yang } \\
\text { dinyatakan kalimat sebelumnya }\end{array}$ \\
\hline Sebaliknya & $\begin{array}{l}\text { Mengacu ke kebalikan dari yang } \\
\text { dinyatakan sebelunya }\end{array}$ \\
\hline Sesungguhnya, bahwasannya & Menyatakan keadaan yang sebenarnya \\
\hline Bahkan, & $\begin{array}{l}\text { Menguatkan keadaan yang dinyatakan } \\
\text { sebelumnya }\end{array}$ \\
\hline Akan tetapi, namun & $\begin{array}{l}\text { Menyatakan keadaan pertentangan } \\
\text { dengan keadaan sebelumnya }\end{array}$ \\
\hline Dengan demikian & Menyatakan konsekuensi \\
\hline Oleh karena itu, oleh sebab itu & Menyatakan akibat \\
\hline Sebelum itu & Menyatakan kejadian yang mendahului \\
\hline
\end{tabular}

\footnotetext{
${ }^{9}$ Ibid, halaman 300-301
} 
Selain konjungsi intra kalimat dan antarkalimat, ada pula konjungsi korelatif. Konjungsi korelatif adalah konjungsi yang menghubungkan dua kata, frasa, atau klausa yang memiliki status sintaksis yang sama tetapi terdiri dari dua bagian yang terpisah. Contoh konjungsi korelatif sebagai berikut.

Baik....., maupun

Demikan rupa...., sehingga

Tidak hanya....., tetapi juga

Sedemikian rupa...., sehingga

Bukan hanya...., melainkan juga

Jangankan ..., pun

Dalam konteks praktis bahasa tulis, konjungsi bisa tidak berfungsi atau tidak memiliki fungsi sebagaimana mestinya jika tidak diletakkan di tempat yang benar. Kesalahan penempatan konjungsi dapat membuat makna kalimat bergeser. Penelitian bertujuan untuk mendeskripsikan disfungsi konjungsi akibat kesalahan penempatan pada makalah mahasiswa serta menentukan pola umum kesalahan penggunaan konjungsi yang berakibat pada disfungsi konjungsi.

\section{B. METODE PENELITIAN}

Penelitian ini menggunakan pendekatan kualitatif. Jenis penelitian ini adalah penelitian deskriptif berorientasi pada disfungsi konjungsi yang terdapat pada makalah mahasiswa.

Tahapan-tahapan penelitian didasarkan pada tahapan penelitian kualitatif yang dikemukakan oleh Mills dan Huberman ${ }^{10}$. Tahap penelitian meliputi, (a)

${ }^{10}$ M.B. Miles, A.M. Huberman, dan J. Saldana, 2013, Qualitative Data Analysis. Thaosand Oaks: Sage Publication. 
membangun kerangka konseptual, (b) merumuskan fokus penelitian, (c) pembatasan penelitian, (d) instrumentasi, (e) pengumpulan data, (f) matrik (g) analisis data, dan (h) pengujian kesimpulan.

1. Membangun kerangka konseptual dapat dilakukan di awal penelitian atau pada tahap persiapan, tetapi dapat terus berkembang seta diverifikasi secara nyata pada saat berlangsungnya penelitian.

2. Merumuskan fokus penelitian berangkat dari satu permasalahan yang menjadi fenomena dan menarik untuk diteliti.

3. Pembatasan penelitian dilakukan dengan mempertimbangkan segi waktu, biaya, dan akses terhadap fokus penelitian yang akan dikaji.

4. Instrumentasi adalah serangakain proses membuat instrumen untuk mengumpulkan data.

5. Pengumpulan data dilakukan di lapangan menggunakan instrumen yang telah disiapkan. Ketika pengumpulan data, dimungkinkan analisis data langsung di lapangan agar tidak kehilangan konteks dari percakapan yang dianalisis.

6. Matrik adalah usaha menyajikan data dengan cara membuat pengkategorisasian data berdasarkan ciri.

7. Analisis data dilakukan dengan cara mengkategorikan tuturan hakim dan terdakwa berdasarkan kerangka teori yang digunakan. Pengkategorian termasuk kegaiatn menganalisis ketaatan dan ketidaktaatan pada kerangka teori yang digunakan.

8. Pengujian kesimpulan atau temuan dilakukan untuk memastikan bahwa kesimpualan atau temuan yang diperoelh sudah sesuai dengan data dari berbagai sudut pandang. 
Sesuai dengan ciri penelitian kualitatif, peneliti adalah instrumen kunci yang bertugas untuk menganalisis data yang lapangan dari berbagai alat pengumpulan data. Pentingnya kehadiran peneliti sebagai instrumen kunci juga dipaparkan oleh Moleong. Menurut Moleong manusia dapat menilai keadaan dan dapat mengambil keputusan yang disarankan penting dan sesuai dengan data yang diperlukan $^{11}$.

Penelitian ini berlokasi di Institut Agama Islam Sunan Giri Bojonegoro. Sumber data dalam penelitian ini adalah makalah mahasiswa semester 3 dalam mata kuliah Bahasa Indonesia. Pengumpulan data dilakukan dengan instrumen tambahan berupa rubrik disfungsi konjungsi.

Analisis data yang akan dilakukan didasarkan pada teori analisis Mills dan Huberman yakni pengumpulan data, reduksi data, penyajian data, dan penarikan simpulan $^{12}$.

1. Analisis data ketika pengumpulan data idealnya adalah sebuah analisis yang jalin menjali. Kunjungan lapangan dilakukan secara berkala dan diselangseling dengan saat diadakannya pengumpula data serta penyajian data. Guna menarik kesimpulan-kesimpulan selama pengumpulan data terjadi. Singkat kata, selama mengumpulkan data, peneliti juga harus menganalisis data sekaligus agar tidak kehilangan konteks percakapan. Hal tersebut tentu membutuhkan dasar teori yang mantap dan kokoh sebelum terjun ke lapangan.

2. Analisis data ketika mereduksi data dilakukan dengan membuang data-data yang dianggap tidak diperlukan atau tidak memenuhi syarat data yang dibutuhkan. Misalnya, setelah mengumpulkan data ada satu dari data yang tidak lengkap maka data tersebut harus dibuang. Pun demikian, jika saat

\footnotetext{
${ }^{11}$ Lexy J Moleong. 2004. Metodologi Penelitian Kualitatif. (Bandung: Remadja Karya), halaman 17

${ }^{12}$ M.B. Miles, A.M. Huberman, dan J. Saldana, op. cit, halaman 17
} 
mereduksi data ada data yang penampilannya aneh dan tidak sama seperti data lain. Data tersebut harus dianalisis karena berkemungkinan menjadi temuan.

3. Analisis data ketika menyajikan data dilakukan dengan pemilahan data berdasarkan kolom matrik yang digunakan. Misalnya digunakan matrik tata waktu, maka seorang peneliti harus menganalisis data mana yang layak masuk kolom pada kurun waktu tertentu. Begitu pula dengan jenis-jenis penyajian data dengan matrik lainnya.

4. Analisis data yang terakhir adalah analisis data yang dilakukan ketika semua data sudah terkumpul dan data sudah disajikan. Menggunakan dasar teori yang mantap dan matang untuk menarik kesimpulan dari data yang terkumpul.

Taktik untuk menguji dan memastikan kesimpulan antara lain yaitu, memeriksa kerepresentasian, memeriksa pengaruh peneliti, triangulasi, memberi bobot pada bukti, membuat pertentangan/ perbandingan, memerikasa makna dari segala sesuatu yang di luar, menggunakan kasus ekstrem, menyingkirkan hubungan palsu, membuat replika temuan, mencari penjelasan tandingan, memberi bukti yang negatif, dan mendapatkan umpan balikan dari informan.

Pada penelitian ini pengecekan keabsahan temuan dilakukan dengan cara triangulasi, yakni pengecekan kevalidan temuan dari berbagai perspektif. Trianggulasi dimaksudkan untuk memeriksa kembali rangkaian data dari beberapa metode pengumpulan data untuk dihubungkan dan memperoleh hasil temuan akhir. Triangulasi juga akan dapat menolong jika peneliti mencari-cari sumber data yang baru. Jadi triangulasi ini digunakan untuk menguji temuan kita dengan mereplikasikan hasil temuan pada sumber data yang baru sehingga tampak apabila temuan tersebut benar, maka temuan tersebut terulang kembali. Tujuan utama kegiatan ini menunjukkan bahwa triangulasi digunakan untuk mengumpulkan dan memeriksa kembali temuan-temuan, dengan mengggunakan sumber-sumber ganda dan cara-cara pemerolehan data, proses pengujian akan dapat dibangun untuk proses perolehan data, dan tidak banyak lagi yang harus dilakukan setelah melaporkan prosedurnya. 


\section{HASIL DAN PEMBAHASAN}

\section{Disfungsi Konjungsi}

Dalam makalah mahasiswa ditemukan beberapa disfungsi konjungsi intrakalimat seperti yang dijelaskan sebagai berikut.

a. Disfungsi Konjungsi Subordinatif Untuk

Kesalahan penggunaan konjungsi untuk dilakukan mahasiswa dalam mengawali rincian sub bab tujuan makalah.

Tujuan makalah ini adalah sebagai berikut.

1) Untuk mengetahui pengertian paragraf

2) Untuk mengetahui syarat-syarat paragraf

3) Untuk mengetahui pembagian paragraf

4) Untuk mengetahui tanda-tanda paragraf

5) Untuk mengetahui rangka atau struktur paragraf

6) Untuk mengetahui pengertian paragarf deduktif dan induktif

7) Untuk mengetahui pembagian paragraf menurut teknik pemaparanya

Konjungsi untuk adalah konjungsi subordinatif tujuan ${ }^{13}$. Konjungsi untuk menunjukkan bahwa kata atau frasa selanjutnya adalah tujuan dari frasa atau kata sebelumnya. Pada data (1) sejatinya tanpa konjungsi untuk kalimat-kalimat dalam uraian telah menunjukkan tujuan makalah. Hal tersebut disebabkan kalimat-kalimat itu berada pada sub bab tujuan dan telah ada kalimat pendahulu yaitu tujuan makalah ini adalah sebagai berikut. Penggunaan konjungsi untuk di awal uraian tujuan tidak diperlukan. Selain itu, konjungsi untuk adalah konjungsi intrakalimat sehinga tidak boleh diletakkan di awal kalimat.

${ }^{13}$ Hasan Alwi, dkk, 2003, Tata Bahasa Baku Bahasa Indonesia, (Jakarta: Balai Pustaka), halaman 289. 
Untuk menandai sebuah paragraf, paragraf dapat ditandai dengan memulai kalimat pertama agak menjorok kedalam, kira-kira lima ketukan mesin ketik atau kira-kira dua centimeter.

Senada dengan data (1) konjungsi untuk pada kalimat pada data (2) di atas mengalami kesalahan penempatan karena diletakkan di awal kalimat. Klausa untuk menandai sebuah paragraf tidak perlu ditulis karena tanpa klausa itu pun kalimat sudah mewakili maksud yang ingin disampaikan.

b. Disfungsi Konjungsi Korelatif dan

Kesalahan penggunaan konjungsi dan dilakukan mahasiswa dengan meletakkan dan di awal kalimat.

Kalimat topik adalah kalimat yang berisi topik yang dibicarakan pengarang. Pengarang meletakan inti maksud pembicaraannya pada kalimat topik. Dan kalimat penjelas adalah kalimat yang mengandung gagasan yang menjelaskan topik atau gagasan utama.

Konjungsi dan tidak boleh diletakan di awal kalimat karena merupakan konjungsi intrakalimat korelatif ${ }^{14}$. Konjungsi dan harus mengapit dua frasa atau klausa dalam satu kalimat. Konjungsi dan bukanlah konjungsi antarkalimat. Jika diletakkan di awal kalimat maka dan tidak memiliki fungsi apapun.

\section{c. Disfungsi Konjungsi Subordinatif Karena}

Konjungsi karena adalah konjungsi intrakalimat subordinatif sebab ${ }^{15}$. Konjungsi karena tidak boleh diletakkan di awal kalimat kecuali ditambah dengan kata oleh dan itu menjadi oleh karena itu. Akan tetapi, konjungsi antarkalimat oleh karena itu tidak cocok diletakan di awal kalimat data (4).

Karena topik paragraf adalah pikiran utama dalam sebuah paragraf, kalimat topik merupakan kalimat utama dalam paragraf

\footnotetext{
${ }^{14}$ Hasan Alwi, dkk. Loc cit.

${ }^{15}$ Hasan Alwi, dkk. Loc cit.
} 
itu. Karena setiap paragraf hanya mempunyai sebuah topik, paragraf itu tentu hanya mempunyai satu kalimat utama.

\section{d. Disfungsi Konjungsi Subordinatif Sebab}

(5)

Sebab, makalah ini tiada sempurna dan masih memiliki banyak kelemahan. Adapun penulis juga berharap semoga makalah ini bisa bermanfaat bagi pembacanya ataupun penelitian selanjutnya.

Konjungsi sebab adalah konjungsi intrakalimat koordinatif yang seharusnya diletakkan di tengah kalimat, bukan di awal kalimat ${ }^{16}$. Pada data (5) kedua kalimat tersebut bisa digantikan dengan satu kalimat yang lebih ringkas sebagai berikut.

Meskipun makalah ini memiliki banyak kelemahan, kami berharap bermanfaat bagi pembaca.

e. Disfungsi Konjungsi Subordinatif Dengan

Konjungsi dengan bermakna alat atau cara. Makna tersebut bergatung pada kalimat yang disertai.

(6)

Dengan modal catatan kaki kelebihannya adalah pembaca dapat langsung dengan cepat mengetahui sumber kutipan itu karena berada pada halaman yang sama.

Konjungsi dengan pada data (6) dimaksudkan untuk menunjukkan cara, tetapi tanpa dengan pun kalimat sudah dapat berarti cara dengan susunan kalimat sebagai berikut.

Catatan kaki memudahkan pembaca mengetahui sumber kutipan.

\footnotetext{
${ }^{16}$ Hasan Alwi, dkk. Loc cit
} 


\section{f. Disfungsi Konjungsi Korelatif}

Konjungsi korelatif berupa dua kata atau frasa yang hadir bersama dalam satu kalimat. Dua kata atau frasa tersebut merupakan pasangan konjungsi untuk menghasilkan hubungan korelatif antar dua kata, frasa, atau klausa dalam suatu kalimat.

(7)

Namun, kalau nama orang itu digunakan sebagai nama benda, nama jenis, dan nama ukuran, maka huruf kapital tidak digunakan. Misalnya, Mesin diesel.

Kesalahan pertama pada data (7) adalah namun...., maka bukanlah pasangan konjungsi korelatif. Namun menyatakan kondisi pertentangan dengan kalimat sebelumnya. Maka menyatakan akibat. Kesalahan kedua adalah keberadaan konjungsi kalau yang membuat penggunaan konjungsi pada kalimat tersebut tidak ringkas. Adanya konjungsi namun, kalau...., maka menjadi tidak memiliki fungsi sebagai mana mestinya. Pada kasus tersebut, konjungsi jika yang diletakkan di dalam kalimat lebih cocok digunakan untuk mengapit prasyarat dan akibatnya. Alternatif kalimat untuk mewakili maksud kalimat tersebut secara lebih ringkas adalah sebagai berikut.

Huruf kapital tidak digunakan jika nama orang digunakan sebagai nama benda, nama jenis, dan nama ukuran.

\section{Pola Kesalahan}

Berdasarkan penjelasan mengenai kesalahan-kesalahan terkait penggunaan konjungsi dalam makalah mahasiswa, dapat ditarik dua pola kesalahan yang sering dilakukan oleh mahasiswa. Pertama, penggunaan konjungsi intrakalimat sebagai konjungsi antarkalimat. Hal tersebut dapat dilihat dari banyak konjungsi intrakalimat, baik koordinatif maupun subordinatif, yang diletakkan di awal kalimat. 
Kedua, boros konjungsi dalam mengungkapkan ide. Pada beberapa kasus mahasiswa menggunakan beberapa konjungsi intrakalimat dan menempatkannya sebagai konjungsi korelatif. Padahal, beberapa konungsi tersebut bisa diwakilkan oleh satu konjungsi saja dengan penataan ulang kalimat.

\section{KESIMPULAN}

Disfungsi konjungsi merupakan kondisi keberadaan konjungsi dalam suatu kalimat tidak berfungsi sama sekali atau tidak berfungsi sebagaimana mestinya. Hal itu dapat disebabkan oleh kesalahan peletakkan konjungsi atau kesalahan pemilihan konjungsi.

Dari serangkaian analisis disimpulkan disfungsi konjungsi pada makalah mahasiswa dialami oleh konjungsi untuk, dan, karena, sebab, dengan, namun, dan maka. Pola kesalahan umum yang sering dilakukan mahasiswa adalah penggunaan konjungsi intrakalimat sebagai konjungsi antarkalimat serta pemborosan konjungsi.

\section{E. DAFTAR PUSTAKA}

Alwi, Hasan., dkk. 2003. Tata Bahasa Baku Bahasa Indonesia. Jakarta: Balai Pustaka.

Chaer, Abdul. 2009. Sintaksis Bahasa Indonesia (Pendekatan Proses). Jakarta: Rineka Cipta.

Halliday, M., \& Hasan, R. 1976. Cohesion In English. London: Longman.

Miles, M.B., Huberman, A.M. dan Saldana, J. 2013. Qualitative Data Analysis. Thaosand Oaks: Sage Publication.

Moleong, Lexy J. 2004. Metodologi Penelitian Kualitatif. Bandung: Remadja Karya

Sumadi. 2009. Sintaksis Bahasa Indonesia. Malang: UM Press.

Tarigan, Henry Guntu. 2009. Pengantar Wacana. Bandung: Angkasa Bandung. 
Widdowson, H.G.2007. Discourse Analysis. New York: Oxford University Press. 